DOI: 10.46340/eujem.2020.6.2.2

Oleksandr Sokhatskyi

ORCID ID: https://orcid.org/0000-0001-8735-866X

Ternopil National Economic University, Ukraine

\title{
MILITARY EXPENDITURES IN SITUATIONS OF ARMED CONFLICTS AND THEIR IMPACT ON THE COUNTRY'S ECONOMY
}

The aim of the research was to identify the impact of military expenditures on the country's economic situation in a state of armed conflict, taking into account new forms of warfare (hybrid war). A generalized analysis of modern armed conflicts has been conducted, which considered both international and internal conflicts, such as civil wars. The relationship between military expenditures and the economic situation of Ukraine, Georgia and Algeria during the active phase of the military conflict has been examined. It has been determined that the state of the economy is affected by the level of investment in the country's defense, the duration of the conflict, and the presence of relevant reforms in the period before and after the conflict.

Keywords: armed conflict, defense budget, hybrid war, investment, macroeconomic indicators, military expenditures.

Problem statement. In the 21st century, armed conflicts and wars continue to accompany the modern world. Their numbers do not decrease, but rather increase. The territory of their occupation is expanding. Local conflicts arising on ethnic or interfaith grounds are constantly supported by external forces, which are guided by their own geopolitical interests. The result of these conflicts is the death of both the military and civilians, including due to hunger, the destruction of the health system, water shortages and environmental pollution.

Wars and armed conflicts in modern conditions are somewhat different from the past and have the socalled hybrid character. They differ in specificity, tactics, and intensity, which require the need to review not only classical methods and strategies for their management, but also approaches to budget planning.

Today's wars are becoming more expensive, which prompts the countries all over the world to increase their military expenditures. So, according to SIPRI, world military expenditures in 2017 reached $\$ 1,739$ billion, exceeding their amount in 2016 by $1.1 \%$ in actual prices. This rate was the highest since the end of the Cold War ${ }^{1}$.

Currently, armed conflicts have a direct impact on the macroeconomic situation in the country. At the time, British professor Paul Collier proved that the estimated cost of a civil war is $2.2 \%$ of annual GDP due to the effect of reduced economic growth. This is due to the destruction of production capacities and infrastructure, loss of population, migration, etc ${ }^{2}$. Wars and armed conflicts, which require an increase in military expenditures, affect domestic and foreign investment, household spending, export-import activities and national currency. In case when income is insufficient to cover military expenditures, countries often rely on alternative sources of financing (in particular, borrowing), which can also hamper future economic growth. The research of the impact of military expenditure growth on the macroeconomic situation in the context of hybrid conflicts is especially relevant for Ukraine since on its territory the war has been waging for six consecutive years unleashed by Russia back in 2014 .

The analysis of recent research and publications. The analysis of publications related to the determination of the military expenditure impact on economic development indicates that this topic is the subject of interest among wide range of both domestic and foreign scientists. The scientific works

\footnotetext{
${ }^{1}$ Stockholm International Peace Research Institute. Official page (2020). SIPRI databases

$<$ https://www.sipri.org/databases $>$ (2020, February, 14).

${ }^{2}$ Баронін, А. (2017). Як військові конфлікти впливають на економіку. Mind.

$<$ https://mind.ua/openmind/20173685-yak-vijskovi-konflikti-vplivayut-na-ekonomiku> (2020, February, 14).
} 
of F. O. Hoffman ${ }^{1}$, D. Kilcullen ${ }^{2}$, V. Mandragel, O. Bodruk, Yu. Mixeev, H. Cherniavskyi ${ }^{3}$, M. Kaldor ${ }^{4}$, A. Bartosh ${ }^{5}$ are focused on clarification of modern armed conflicts and wars essence, their characteristic features and differences, causes of occurrence.

The study of military expenditures macroeconomic effects has received considerable attention from specialists in military-economic security. As part of their research, empirical verification of theoretical hypotheses was carried out regarding the directions of the military expenditures impact on economic growth. Meanwhile, the impact of military expenditures usually is determined through the effect of demand, supply and security. These issues have been studied by Sh. Ahmed, I. Saba ${ }^{6}$, O. Chernyak, H, Harlamova ${ }^{7}$, A. Knobel, B. Chokaeva, A. Mironova ${ }^{8}$. However, scientists have not come to a clear conclusion. Moreover, the amount of research on increasing military expenditures impact on the country's economy in a state of an armed conflict is insufficient.

The purpose of the article is to assess the impact of military expenditures on country's macroeconomic indicators in state of an armed conflict in order to improve the defense budget planning process.

Main material. Since the end of World War II, armed conflicts and wars on the planet do not cease. Some of them are still ongoing, others have entered the phase of a frozen conflict. The most protracted are the armed conflicts in India (Jammu and Kashmir) and Palestine, which have continued for more than 72 years. According to the data of the Center for Systemic Peace (CSP), there were 36 wars at the beginning of 2017. 28 countries are directly involved in them. Of these, nearly half (13 countries) have protracted conflicts - those that last more than 10 years ${ }^{9}$.

According to Stockholm International Peace Research Institute (SIPRI), in 2017 armed conflicts continued in at least 22 countries, and many non-governmental armed groups and external parties took part in them ${ }^{10}$. Different estimates of the conflicts number are due to different approaches to their classification and definition.

Thus, SIPRI data is based on the Uppsala Conflict Data Program (UCDP), according to which armed conflicts include conflicts related to armed violence between two or more countries (international armed conflict) and a conflict between a country and one or more organized non-governmental armed groups (internal armed conflict). According to UCDP, in 2014-2016 there were much more armed conflicts (on average, 47 per year) than in any three-year period throughout 2007-2013 (on average, 35 per year); the vast majority of them are internal ${ }^{11}$.

At the same time, the number of armed groups involved in one conflict is increasing. The peaceful resolution of these conflicts is hindered by their internationalization. More than a third of ongoing armed

\footnotetext{
${ }^{1}$ Hoffman, F. O. (2009). Hybrid Threats : Reconceptualizing the Evolving Character of Modern Conflict. Strategic Forum, 240, 1-8.<https://www.academia.edu/22897432/Hybrid_Threats_Reconceptualizing_the_Evolving_ Character_of_Modern_Conflict>(2020, February,14).

${ }^{2}$ Kilcullen, D. (2013). Out of the Mountains: The Coming age of the Urban Guerrilla. Oxford: University Press.

${ }^{3}$ Міхєєв, Ю. У., Чернявський, Г. П., Турченко, Ю. В., Пінчук, О. У. (2016). Дефініції поняття «гібридна війна». Збірник наукових пращзь Військового інституту КНУ ім. Т.Шевченка, 51, 124-131.

$<$ http://nbuv.gov.ua/UJRN/Znpviknu_2016_51_18> (2020, February, 14).

${ }^{4}$ Калдор, М. (2015). Новые и старые войны:: организованное насилие в глобальну эпоху. Москва: Издательство Института Гайдара.

${ }^{5}$ Бартош, А. А. (2015). Гибридные войны как проявление глобальной критичности современного мира. Геополитика и безопасность, 1 (29), 71-79.

${ }^{6}$ Шахід, А., Саба, I. (2015). Економічне зростання країн і військові витрати: аналіз взаємозв'язку. Міжнародна економічна політика, 2 (23), 50-76.

${ }^{7}$ Арженовський, С. В. (2016). Военные расходы и экономический рост: эконометрические оценки зависимости. Экономический анализ: теория и практика, 9, 153-164.

${ }^{8}$ Кнобель, А. Ю., Чокаев, Б. В., Миронов, А. К. (2015). Сравнительный анализ эффективности госрасходов в сфере национальной обороны и правоохранительной деятельности. SSRN Electronic Journal.

$<$ http://dx.doi.org/10.2139/ssrn.2624542> (2020, February, 14).

${ }^{9}$ Гомон, Д. (2017). Світова мапа війн. Де і за що сьогодні воює людство. Ecnpeco.

$<$ https://espreso.tv/article/2017/07/24/khto_z_kym_i_za_scho_voyuye_sogodni_v_sviti $>(2020$, February, 14).

${ }^{10}$ Stockholm International Peace Research Institute. Official page (2020). SIPRI databases

$<$ https://www.sipri.org/databases $>$ (2020, February, 14).

${ }^{11}$ Odermatt, J. (2013). Between law and reality: "new wars" and "internationalized armed conflict".

Amsterdam law forum, 5 (3), 19-32.
} 
conflicts are internationalized - judging by the participation of foreign forces, sometimes, but not always, as direct combatants. According to the SIPRI, the four armed conflicts in the Middle East and North Africa (Iraq, Libya, Syria and Yemen) are continued primarily due to the participation of foreign forces.

Armed conflicts, whether internal or international, are taking place on almost the entire planet. Thus, in Central and South America (El Salvador, Mexico, Paraguay, Guatemala, Venezuela) political and criminal violence can be rank alongside the traditional armed conflict, although it does not fall within the definition of armed conflict. In 2017, active armed conflicts also took place in Asia and Oceania (Afghanistan, India, Myanmar, Pakistan and the Philippines). Tensions remain in Europe due to unresolved conflicts in Cyprus, Georgia (Abkhazia and South Ossetia), Moldova (Transnistria), Kosovo, Armenia and Azerbaijan (the Nagorny Karabakh conflict). The issue of national security was especially acute for Ukraine, after the Russian occupation of Crimea in March 2014 and the unfolding of a military conflict in the East of Ukraine in April 2015. The hotspots are in the Middle East and North Africa, where in 2017 seven active armed conflicts took place: Egypt, Iraq, Israel-Palestine, Libya, Syria, Turkey, Yemen. The same number of active armed conflicts occurs in Equatorial Africa: in Mali, Nigeria, the Central African Republic (CAR), the Democratic Republic of the Congo (DRC), Ethiopia, Somalia, and in the South of Sudan. In addition, in several other countries have been observed post-war conflicts and dangerous tensions which can lead to a potential armed conflict ${ }^{1}$.

As noted, the existing conflicts are internationalized to a large extent, and more and more countries are trying to test the possibility of changing already established borders, to increase their influence and reduce the influence of their rivals. After the end of the Cold War the power and alliances of the United States made it possible to establish certain law and order in different regions of the West. However, with the diminishing influence of the West, leaders from various countries around the world are trying to check how much further they can go $^{2}$. Examples include the actions of Russia, China, Saudi Arabia, Iran, etc.

Unresolved armed conflicts are in most cases fatal (for the civilian population also), and cause significant negative social consequences. Thus, only in 2017, over 15 thousand people died because of explosive weapons. Throughout 10 years, from 2007 to 2017, the number of civilian deaths from armed conflicts has doubled, as has the death toll of indirect lethal manifestations such as malnutrition, hunger, pollution of water supplies and the destruction of the health system which always accompanies such conflicts $^{3}$. According to SIPRI, in the first 11 months of 2017, at least 15,399 civilians died from explosive weapons, the vast majority in cities, representing a $42 \%$ increase over the previous year ${ }^{4}$. During the armed conflict as at August 20,2019, only in Ukraine 4,175 people died, and this number continues to increase.

In addition to the deaths of the military and civilians, armed conflicts are accompanied by relocation of people, when they have to leave their homes because of the bombing. According to the UN High Commissioner for Refugees, 28,300 people are forced to leave their homes every day due to armed conflicts and persecution. The number of forcibly displaced persons in the world exceeds 65 million and has grown sharply in recent years, mainly as a result of violent conflicts ${ }^{5}$. Another consequence of armed conflict is hunger, which negatively affects people's lives on the planet in a scale comparable to worsening climatic conditions ${ }^{6}$.

In 2017, armed conflicts exacerbated food security problems in Yemen, South Sudan, Syria, Lebanon, the Central African Republic, Afghanistan and Somalia. In these countries, a quarter of the population experienced a critical or extreme level of food shortages. Violent actions during wars and armed conflicts lead to the destruction of infrastructure, health system and other parts of social infrastructure.

\footnotetext{
${ }^{1}$ Stockholm International Peace Research Institute. Official page (2020). SIPRI databases

$<$ https://www.sipri.org/databases $>$ (2020, February, 14).

2 Маллі, Р. (2019). Десять конфліктів, за якими потрібно стежити в 2019 році, 1. 112.иа

$<$ https://ua.112.ua/mnenie/desiat-konfliktiv-za-iakymy-potribno-stezhyty-v-2019-rotsi-chastyna-1-475681.html > (2020, February, 14).

${ }^{3}$ United Nations, World Bank. (2018). Pathways for Peace : Inclusive Approaches to Preventing Violent Conflict. Washington, DC: World Bank. <https://openknowledge.worldbank.org/handle/10986/28337> (2020, February, 14).

${ }^{4}$ Stockholm International Peace Research Institute. Official page (2020). SIPRI databases

$<$ https://www.sipri.org/databases $>$ (2020, February, 14).

${ }^{5}$ UNHCR (2020). Figures at a glance. <https://www.unhcr.org/figures-at-a-glance.html > (2020, February, 14).

${ }^{6}$ Food and agriculture organization of the United Nations (2017). The state of Food security and Nutrition in the world: Building Resilience for Peace and Food security. <http://www.fao.org/3/a-i7695e.pdf> (2020, February, 14).
} 
Today's conflicts are slightly different than conflicts of the past, both in terms of their goals and methods. In the era of rapid digitalization of society, not only direct military actions, but to a greater extent non-military instruments (information, economic) are used. In addition, rapid technological changes are modifying and improving military means of warfare. That has led to the emergence of a new, hybrid type of war and armed conflict.

In today's conditions, conduction of military operations will require a corresponding increase in defense and military expenditures. So, in 2018 , world military expenditures rose to $\$ 1.8$ trillion to a total $2.1 \%$ of world GDP, which is $2.6 \%$ more than in $2017^{1}$.

The deterioration of security, the growing number of armed conflicts and the growth in military expenditures are prompting governments to determine sufficient funding for the border defense. The core of this process should be an analysis of the military expenditures impact on economic development.

Today, there is a lot of research that determines the macroeconomic effects of military expenditures. However, the magnitude of military expenditures and their impact on country's macroeconomic indicators will largely depend on whether the country is a participant in an armed conflict or war, on whose territory military operations are taken place, on the effectiveness of government actions, the duration of a conflict, and others. Particularly noteworthy in this regard is the study of the UK economist Mark Harrison, which showed that in some cases due to the US reforms during the World War II, it was possible to pull the national economy out of the Great Depression mainly due to defense industry orders. For example, US GDP from 1938 to 1954 increased from $\$ 800$ billion to $\$ 1.444$ trillion, UK GDP - from $\$ 284$ billion to $\$ 334$ billion. The dynamics showed a steady growth of US GDP until 1944. A similar, albeit slightly smaller growth, was observed in the UK where the war took place.

At the same time, quite high amounts of military expenditures that were spent during the war should be noted. The total military expenditures of all the warring countries (USA, USSR, Great Britain, Germany, Japan) exceeded $\$ 1,117$ billion, which is twice as much as the military budgets during the World War I. The relative volumes of military expenditures also increased substantially. During the war their share in the expenditures section of budget in USA was $43 \%$, in Great Britain - 55.7\%, in Germany $-57.8 \%$, in Japan $49.7 \%$, in the USSR - 55\%. The average annual changes in GDP (in USD) during the war (1938-1945) are shown in Fig. 1.

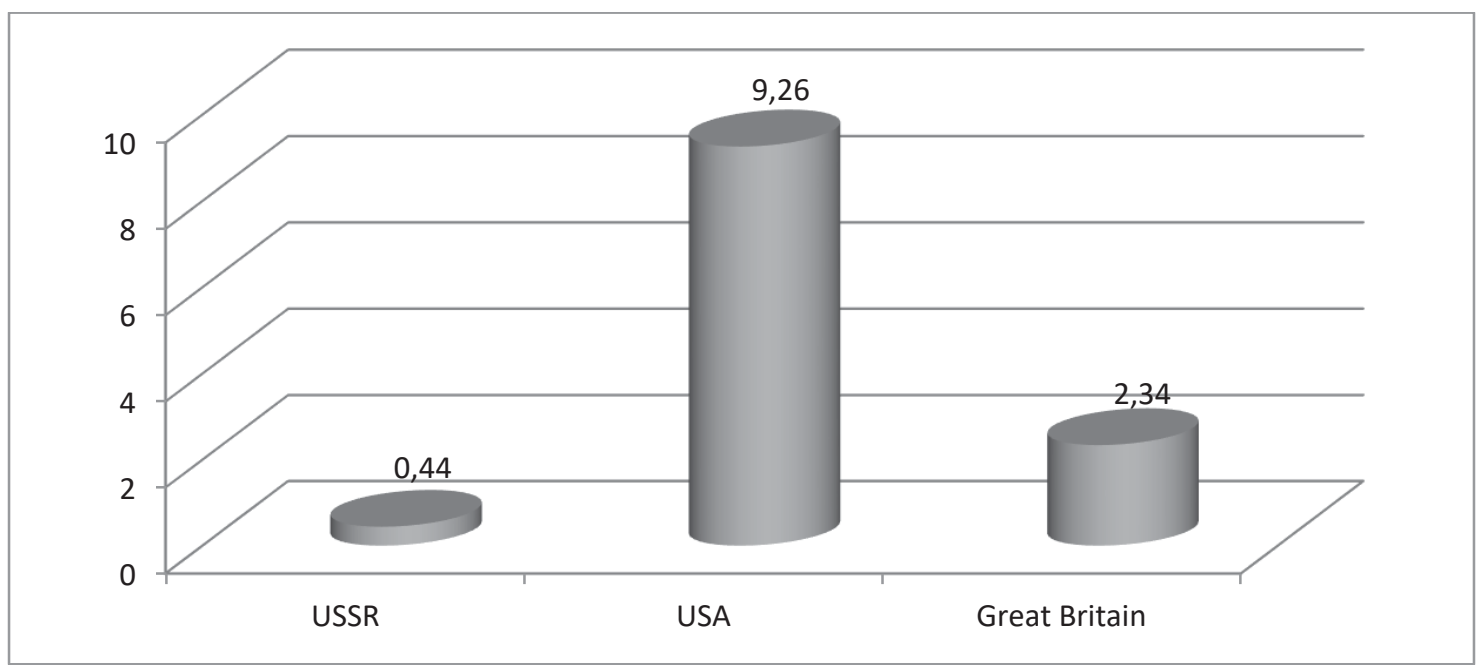

Fig. 1. Average annual changes in GDP (in USD) of the USSR, USA and Great Britain (1938-1945)

Source: ${ }^{2}$

\footnotetext{
${ }^{1}$ Вацяк, Я. (2019). Військові витрати України зросли на 21\%. Українські новини. $<$ https://ukranews.com/ua/news/629282-vijskovi-vytraty-svitu-i-ukrayiny-zrosly> (2020, February, 14).

${ }^{2}$ Скрынченко, Б. (2015). Развитие военной экономики в 20-м веке. Вестник Московского университета имени С. Ю. Витте. Серия: Экономика и управление, 1 (12), 57-61.
} 
Modern armed conflicts are certainly not comparable with World War II, both in scale and loss, and in the costs of their conduct. However, they also have devastating consequences, and significant resources are spent on their management. In 2014, after the outbreak of armed conflict with Russia and annexation of Crimea, Ukraine faced with the problem of insufficient funding for the country's defense, which became one of the main reasons for its unpreparedness to confront the enemy. From 2007 to 2013, defense expenditures in Ukraine decreased almost every year and amounted to only $1.02 \%$ of GDP in 2013 (Fig. 2).

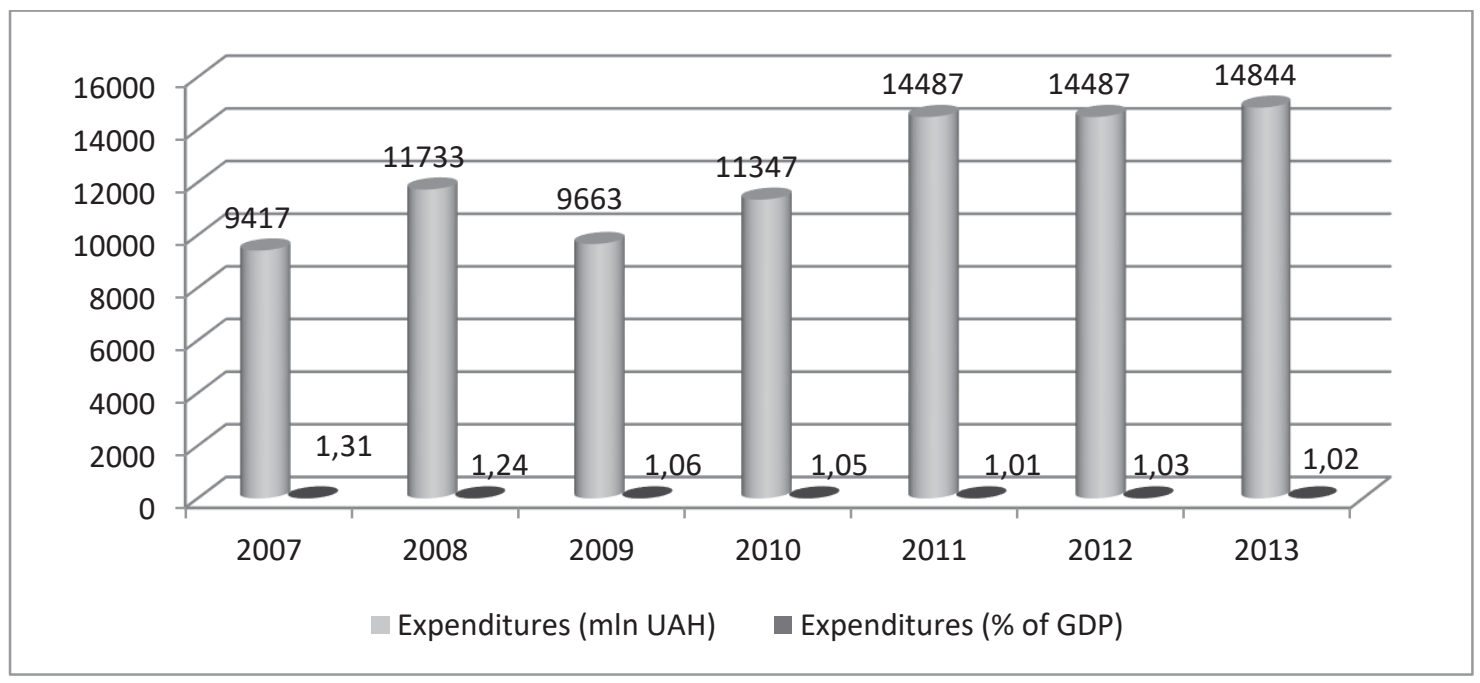

Fig. 2. Defense expenditures of Ukraine in 2007-2013

\section{Source: Ministry of Finance of Ukraine ${ }^{1}$}

The large drop in the actual volumes of financing the Ukrainian defense capacity was observed in 2009 - the rate of decline was $44.4 \%$ (recalculated in USD). However, in 2014, the country had to change its approach to financing military expenditures, as evidenced by the data in Fig. 3.

The outbreak of the military conflict also showed a sharp drop in the main macroeconomic indicators characterizing the state of economic development. One of the main macroeconomic indicators which most accurately describes the state of economic development is GDP per capita. The dynamics of this indicator from 2013 to 2018 is shown in Table 1.

As shown by the data in Table 1, the nominal GDP per capita in UAH grew over the entire period. Although, the same indicator calculated in USD has shown a sharp drop since the beginning of military aggression (the drop was $25.2 \%$ in 2014 and 29.8\% in 2015). Despite the gradual growth of this indicator since 2016, its level in 2018 could not reach the value of the pre-war period. The discrepancies in estimation of GDP in national currency and USD are due to the growth of the USD and the devaluation of the UAH. Thus, in the first year of the conflict, the devaluation of the UAH reached $63.4 \%$.

In reality, the Ukrainian economy and well-being of its citizens has substantially declined. One of the significant reasons was the loss of part of Ukraine with its enterprises, infrastructure, etc. According to German experts, before the events of 2014, the Donbass provided $1 / 4$ of all exports and more than $15 \%$ of all investments. Since August 2014, the level of industrial production in the Donetsk and Luhansk regions dropped by 60 and $85 \%$ respectively ${ }^{2}$, which affect the real state of the economy.

\footnotetext{
${ }^{1}$ Міністерство фінансів України (2020). Статистичний збірник. <https://www.mof.gov.ua/uk/statistichnijzbirnik> (2020, February, 14).

${ }^{2}$ Bluszcz, J., Valente, M. (2019). The War in Europe: Economic Costs of the Ukrainian Conflict. DIW Berlin: German Institute for Economic Research. <https://www.diw.de/documents/publikationen/73/diw_01.c.622006.de/dp1804.pdf> (2020, February, 14).
} 


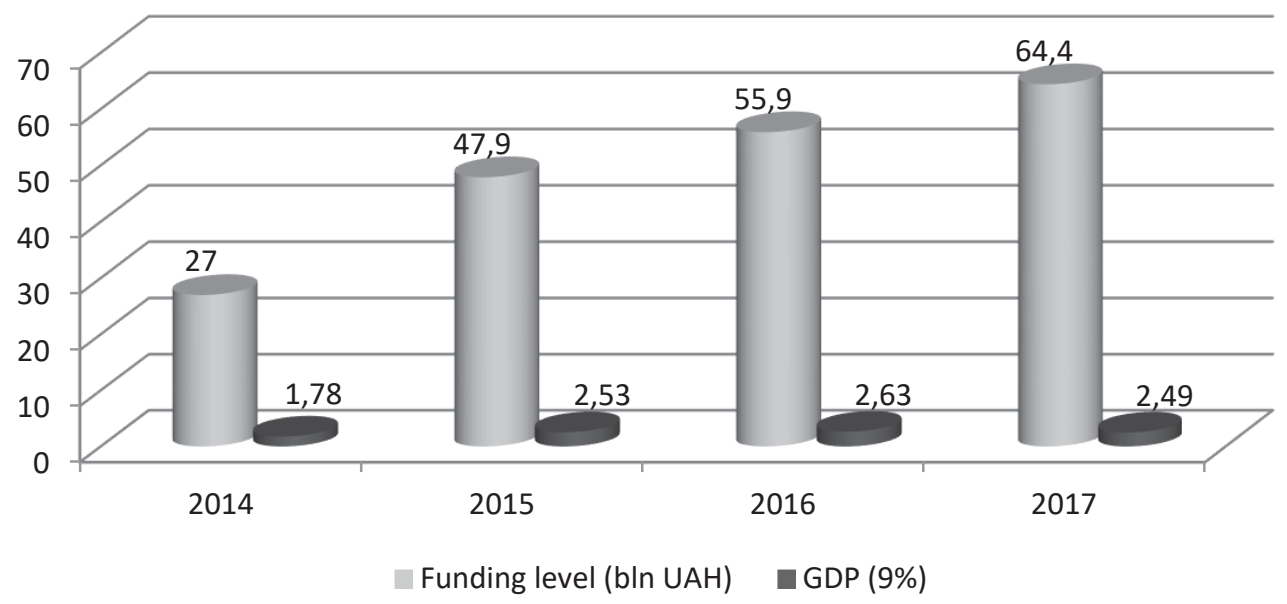

Fig. 3. Financing of military forces of Ukraine in 2014-2017

Source: ${ }^{1}$

Table 1

GDP per capita growth rate in Ukraine

\begin{tabular}{|l|c|c|c|c|c|c|}
\hline \multicolumn{1}{|c|}{ Years } & \multicolumn{3}{|c|}{ GDP per capita (UAH) } & \multicolumn{3}{c|}{ GDP per capita (USD) } \\
\hline 2013 & 31988,7 & $+1076,2$ & - & 4030,3 & $+173,5$ & - \\
\hline 2014 & 35834 & $+3845,3$ & $+12,0 \%$ & 3014,6 & $-1015,7$ & $-25,2 \%$ \\
\hline 2015 & 46210,2 & $+10376,2$ & $+29,0 \%$ & 2115,4 & $-899,2$ & $-29,8 \%$ \\
\hline 2016 & 55853,5 & $+9643,3$ & $+20,9 \%$ & 2185,9 & $+70,5$ & $+3,5 \%$ \\
\hline 2017 & 70224,3 & $+14370,8$ & $+25,7 \%$ & 2640,3 & $+454,4$ & $+20,8 \%$ \\
\hline 2018 & 84192,0 & $+13967,7$ & $+19,9 \%$ & 3095,2 & $+454,9$ & $+17, \%$ \\
\hline
\end{tabular}

Source: MinFin ${ }^{2}$

The loss of territories that provided the country's export share, along with other factors, affected export performance, which in turn is a source of budget replenishment. From 2013 to 2016, there was a negative trend in the export of goods and services in Ukraine. And only in 2017, there was an increase in the export to $\$ 43.3$ billion, which was $19 \%$ more than in 2016. According to the results of 2018 , the total export of Ukraine amounted to $\$ 47.3$ billion.

The armed conflict unleashed by Russia also affected the volumes of both internal and external investments, which provide long-term investments of material resources by non-resident companies in the country's economy. The dynamics of foreign investment in the economy of Ukraine from 2012 to 2018 are shown in Fig. 4.

\footnotetext{
${ }^{1}$ Мороз, Т. (2017). Бюджет Міноборони - 2017: на технічне підсилення війська спрямують 18\% коштів, а «бойові» доплати зростуть до 6 тисяч. Ветерани. $<\mathrm{http}$ //veterano.com.ua/index.php?option=com_content\&view=article\&id= 3887:byudzhet-minoboroni-2017-na-tekhnichne-pidsilennya-vijska-spryamuyut-18-koshtiv-a-bojovi-doplati-zrostutdo-6-tisyach\&catid=16\&Itemid=214 $>(2020$, February, 14).

${ }^{2}$ Мінфін (2020). Валовий внутрішній продукт в Україні. <http://index.minfin.com.ua>economy>gdp> (2020, February, 14).
} 


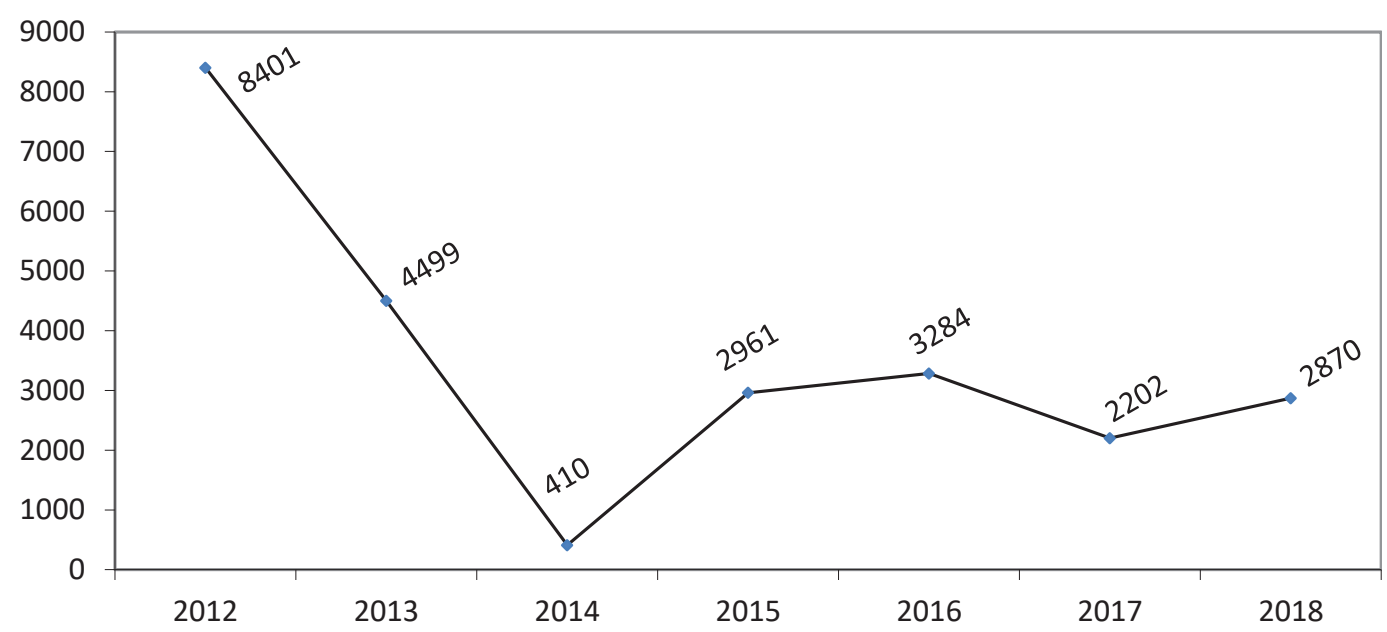

Fig. 4. The dynamics of foreign direct investment in the economy of Ukraine

Source: UkrStat ${ }^{1}$

According to Figure 4, there was a rapid drop in foreign direct investment in the country's economy during 2013-2014, and their recovery occurred only in 2015. Risks arising from the outbreak of the conflict and negative expectations of investors determine the freezing of investments or their outflow from dangerous territories. Similar processes are taking place with regard to domestic investment. Composition of production volumes, a decrease in export earnings, negative investment trends, as well as a need to increase expenditures on the country's defense capabilities, are becoming the main incentives for increasing borrowing volumes. The total gross external debt in relation to the GDP of Ukraine for 20132018 is presented in Figure 5.

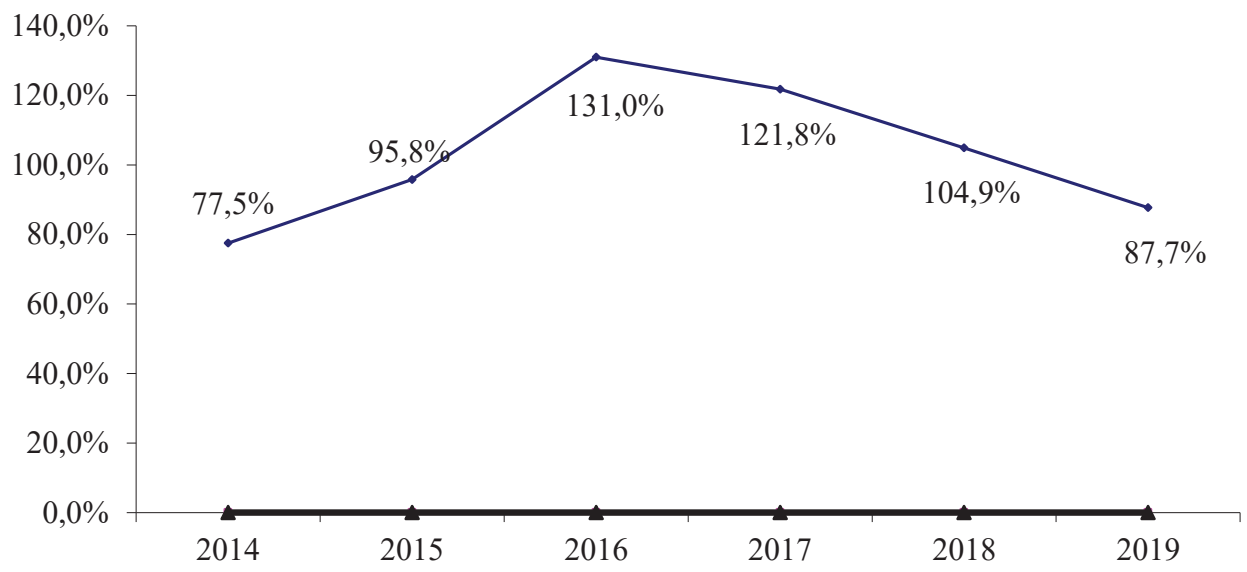

Figure 5. The ratio of gross external debt of Ukraine

Source: ${ }^{2}$

\footnotetext{
${ }^{1}$ Державна служба статистики України (2020). Головна сторінка <http://www.ukrstat.gov.ua> (2020, February, 14).

2 Публічний аудит (2019). Як економіка України опинилася на дні та як вивести ї̈ з теперішнього стану. $<$ http://publicaudit.com.ua/reports-on-audit/globalnyj-analiz-bazovyh-makroekonomichnyh-pokaznykiv-ukrayiny2013-2018-rr/> (2020, February, 14).
} 
According to Figure 5, during the first two years of the military conflict Ukraine almost doubled the ratio of public debt to GDP. And only in 2016, this indicator demonstrated a positive trend. However, it should be noted that this trend was ensured due to a decrease in corporate debt, although in general Ukraine increased external debt during this period, as evidenced by the data in Table 2 .

Table 2

Total gross external debt of Ukraine (mln. USD)

\begin{tabular}{|l|c|c|c|c|c|c|}
\hline & $\mathbf{2 0 1 3}$ & $\mathbf{2 0 1 4}$ & $\mathbf{2 0 1 5}$ & $\mathbf{2 0 1 6}$ & $\mathbf{2 0 1 7}$ & $\mathbf{2 0 1 8}$ \\
\hline $\begin{array}{l}\text { General government } \\
\text { sector }\end{array}$ & 29922 & 32884 & 35959 & 36495 & 38886 & 40128 \\
\hline Central Bank & 1775 & 2176 & 6743 & 6242 & 7438 & 7938 \\
\hline $\begin{array}{l}\text { Other depository } \\
\text { corporations }\end{array}$ & 22555 & 18752 & 12823 & 8966 & 6228 & 5797 \\
\hline Other sectors & 76642 & 62228 & 53581 & 52207 & 53347 & 51430 \\
\hline $\begin{array}{l}\text { Direct investment: } \\
\text { intercompany debt }\end{array}$ & 11185 & 9257 & 8562 & 8614 & 9552 & 9414 \\
\hline Gross external debt & 142079 & 125297 & 117668 & 112524 & 115451 & 114707 \\
\hline
\end{tabular}

Source: ${ }^{1}$

So, the analysis shows that the beginning of the military conflict in Ukraine in 2014 and the need to increase military expenditures caused a rapid decline in the country's economic development and the welfare of its population during the first two years. In the following years, which were accompanied by a further increase in military expenditures, the country's economy gradually began to adapt, compensated for losses and demonstrated positive dynamics.

As noted, armed conflicts can last long enough, as for example in Ukraine, or be quite short-lived, but also be accompanied by losses. On August 8, 2008, Russia quite openly invaded Georgia. Russian military operation lasted for five days and ended with the occupation of Uhinvalskyi region, which amounts to $20 \%$ of the country's territory. By the beginning of the war, the budget of the Georgian defense department, unlike Ukraine, was quite substantial and grew at a significant pace. Thus, its size from 2004 to 2008 increased by almost 9 times and at the beginning of the aggression amounted to $\$ 880$ million. In the general structure of national expenditures, these expenditures for the indicated period reached $8 \%$ of GDP. Since 2009, official expenditures of the Georgian defense department have been reduced to $\$ 536$ million (almost $40 \%$ ), or to $4.8 \%$ of GDP. At the same time, significant amounts of military-humanitarian aid from the US and NATO were allocated to military expenditures.

The macroeconomic situation at the beginning of the armed conflict was also different from the situation in Ukraine. In the years preceding the war, Georgia's GDP grew to $\$ 12.8$ billion in 2008, compared with $\$ 4$ billion in 2003. Income per capita rose from $\$ 772$ in 2002 to $\$ 3,325$ in 2008 . The ratio of external public debt to GDP decreased to 22\% in 2007 against 54\% in 2003. Foreign direct investments in this prewar period increased from $\$ 160.2$ million up to $\$ 1.75$ billion per year ${ }^{2}$.

However, the war, in addition to infrastructure and human losses, also affected the economic situation despite a short period of time. According to the results of 2009, the decline in Georgia's GDP was 3.8\%. GDP per capita has also decreased from $\$ 3,325$ in 2008 to $\$ 2,812$ in 2009.

Nonetheless, the Georgian economy resumed its growth by $6.4 \%$ in 2010 . Of course, a significant role in economic recovery had an international aid, primarily from the International Monetary Fund. However, this assistance was provided due to the reforms that were carried out both before the war and in the post-war

\footnotetext{
${ }^{1}$ Публічний аудит (2019). Як економіка України опинилася на дні та як вивести ї̈ з теперішнього стану. $<$ http://publicaudit.com.ua/reports-on-audit/globalnyj-analiz-bazovyh-makroekonomichnyh-pokaznykivukrayiny2013-2018-rr/> (2020, February, 14).

2 Макфарлейн, Н. (2012). Постреволюційна Грузія на межі? Критика.

$<$ https://krytyka.com/ua/articles/postrevolyutsiyna-hruziya-na-mezhi> (2020, February, 14).
} 
period. There was also a drop in foreign direct investment from $\$ 1.75$ billion in 2007 to $\$ 658$ million, although it did not lead to a general economic decline.

Therefore, as the experience of Georgia shows, a short-term armed conflict, accompanied by the occupation of the territory, does not always lead to an increase in military expenditures. This is especially true for countries that have reformed and well-armed armies. Despite the deterioration of the macroeconomic situation after the end of the armed conflict, the economic situation recovers much faster in case of a short-term conflict.

Armed conflicts can be not only international, which was discussed earlier, but also internal, like a civil war. An example of such a conflict is the civil war in Algeria (1991-2002). During the years of this civil war between the government and the Islamists, about 200 thousand people died, about 2 million people became internal refugees, and another 2 million became victims. Material losses of the country were calculated in billions of USD ${ }^{1}$.

The destruction of production capacities and the loss of the ability to use limited agricultural land negatively affected the GDP indicator during the conflict. If before the war, it was $\$ 2359$, then in $2002-$ $\$ 1806$. Its relative fluctuation was observed during 10 years of the conflict.

Similarly to the armed conflict in Ukraine, Algeria's military expenditures also increased throughout the entire period of the conflict, as shown in Figure 6.

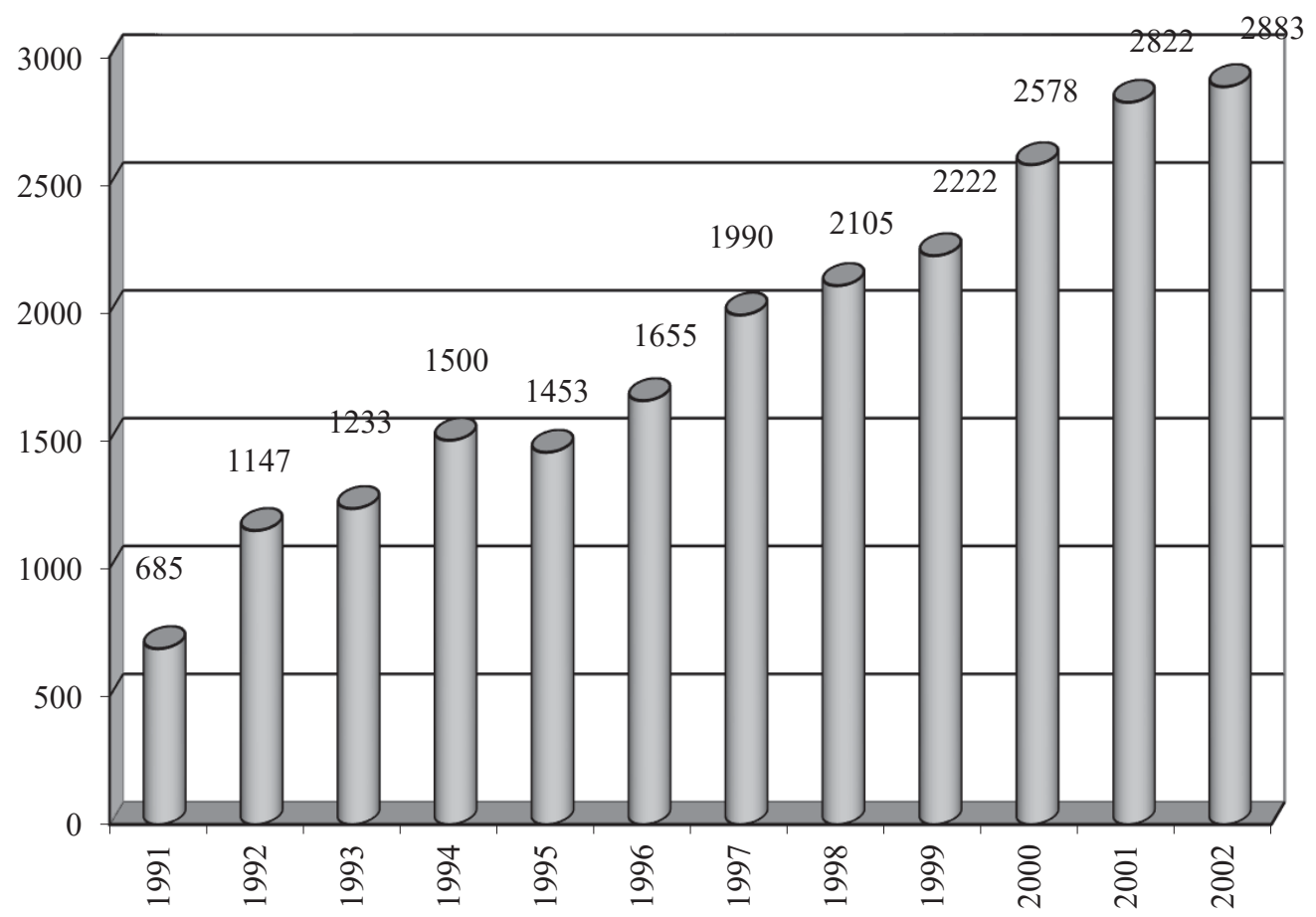

Fig. 6. Military expenditures of Algeria from 1991 to 2002

\section{Source: SIPRI $I^{2}$}

The civil war in Algeria affected the exchange rate of the national currency. The devaluation of the Algerian dinar in the first year of the war was even greater than in Ukraine $-92.3 \%$. The armed conflict also affected the country's external debt. The outflow of foreign innovation and the need for loans aimed at country's defense prompted the Algerian government to increase external debt. While at the beginning

\footnotetext{
1 Долгов, Б. (2014). Алжир. Россия и мусульманский мир. $<$ https://cyberleninka.ru/article/n/alzhir $>$ (2020, February, 14).

${ }^{2}$ Stockholm International Peace Research Institute. Official page (2020). SIPRI databases

$<$ https://www.sipri.org/databases $>$ (2020, February, 14).
} 
of the war the external debt as a percentage of GDP was $46.9 \%$, then in the year of the conflict it grew to $61 \%$. In the following years, this indicator showed mixed trends, which was determined by the development of the economy and international assistance, as well as the price of oil and gas, which are Algeria's main export goods.

\section{Conclusions.}

1. The transformation of the bipolar world into a multipolar system in the 21 st century is accompanied by a buildup of military threats and an increase in the number of both international and internal armed conflicts.

2. As a rule, prolonged armed conflicts, international or internal, are accompanied by an increase in military expenditures. However, their pace depends primarily on an armed forces state at the beginning of a conflict. In the case of short-term conflicts (Georgia), this thesis is not confirmed.

3. Armed conflicts have a negative impact on the country's macroeconomic indicators - GDP per capita, foreign direct investment, public debt and exchange rates. The negative dynamics of these indicators can be seen for long and short-term armed conflicts, both for international and internal ones. However, in prolonged conflicts economic recovery usually occurs after two years, even if they continue. The country's economy is recovering much faster with short-term conflicts.

4. The positive impact of military expenditures can be ensured by the effectiveness of their use an increase in arms exports, production of dual-use goods, etc. Overcoming the negative impact of armed conflict can be provided through reforms in the economic sector, increasing of investment protection level and improving the investment climate, which Georgia has successfully demonstrated.

\section{References:}

1. Arzhenovskij, S. V. (2016). Voennye rashody i ekonomicheskij rost: ekonometricheskie ocenki zavisimosti [Military spending and economic growth: econometric estimates of dependency]. Ekonomicheskij analiz: teorija I praktika [Economic analysis: theory and practice,], 9, 153-164. [in Russian].

2. Baronin, A. (2017). Yak vijskovi konflikty vplyvayut na ekonomiku. How military conflicts affect the economy. Mind. $<$ https://mind.ua/openmind/20173685-yak-vijskovi-konflikti-vplivayut-na-ekonomiku> (2020, February, 14). [in Ukrainian].

3. Bartosh, A. A. (2015). Gibridnye vojny kak projavlenie globalnoj kritichnosti sovremennogo mira [Hybrid wars as a manifestation of the global criticality of the modern world]. Geopolitika i bezopasnost [Geopolitics and Security], 1 (29), 71-79. [in Russian].

4. Bluszcz, J., Valente, M. (2019). The War in Europe: Economic Costs of the Ukrainian Conflict. DIW Berlin: German Institute for Economic Research. <https:/www.diw.de/documents/publikationen/73/diw_01.c.622006.de/ dp1804.pdf> (2020, February, 14). [in English].

5. Derzhavna sluzhba statystyky Ukrayiny [State Statistics Service of Ukraine]. Official page. $<$ http://www.ukrstat.gov.ua $>$ (2020, February, 14). [in Ukrainian].

6. Dolgov, B. (2014). Alzhir [Algeria]. Rossija i musulmanskij mir [Russia and the Muslim world]. $<$ https://cyberleninka.ru/article/n/alzhir $>$ (2020, February, 14). [in Russian].

7. Figures at a glance. UNHCR. <https://www.unhcr.org/figures-at-a-glance.html> (2020, February, 14). [in English].

8. Gomon, D. (2017). Svitova mapa vijn. De i za shho sogodni voyuye lyudstvo [World map of wars. Where and for what mankind is at war today]. Espresso. <https://espreso.tv/article/2017/07/24/khto_z_kym_i_za_scho_ voyuye_sogodni_v_sviti> (2020, February, 14). [in Ukrainian].

9. Hoffman, F. O. (2009). Hybrid Threats : Reconceptualizing the Evolving Character of Modern Conflict. Strategic Forum, 240, 1-8.<https://www.academia.edu/22897432/Hybrid_Threats_Reconceptualizing_the_Evolving_ Character of Modern Conflict $>(2020$, February,14). [in English].

10. Kaldor, M. (2015). Novye i starye vojny: organizovannoe nasilie v globalnuju epohu [New and old wars: organized violence in the global era]. Moscow: Izdatelstvo Instituta Gajdara. [in Russian].

11. Kilcullen, D. (2013). Out of the Mountains: The Coming age of the Urban Guerrilla. Oxford: University Press. [in English].

12. Knobel, A. Ju., Chokaev, B. V., Mironov, A. K. (2015). Sravnitelnyj analiz effektivnosti gosrashodov v sfere nacionalnoj oborony i pravoohranitelnoj dejatelnosti [Comparative analysis of the effectiveness of government spending in the field of national defense and law enforcement]. SSRN Electronic Journal. $<$ http://dx.doi.org/10.2139/ssrn.2624542> (2020, February, 14). [in Russian].

13. Makfarlejn, N. (2012). Postrevolyucijna Gruziya na mezhi? Post-revolutionary Georgia on the brink?]. Krytyka [Critics]. <https://krytyka.com/ua/articles/postrevolyutsiyna-hruziya-na-mezhi> (2020, February, 14). [in Ukrainian].

14. Malli, R. (2019). Desyat konfliktiv, za yakymy potribno stezhyty v 2019 roci. Chastyna 1 [Ten conflicts to watch in 2019. Part 1]. 112. <https://ua.112.ua/mnenie/desiat-konfliktiv-za-iakymy-potribno-stezhyty-v-2019-rotsichastyna-1-475681.html $>$ (2020, February, 14). [in Ukrainian]. 
15. Mihyeyev, Yu. U., Chernyavskyj, G. P., Turchenko, Yu. V., Pinchuk, O. U. (2016). Definiciyi ponyattya «gibrydna vijna». [Definitions of the concept of "hybrid war"]. Zbirnyk naukovyh pracz Vijskovogo instytutu KNU im. T. Shevchenka [Collection of scientific works of the Military Institute of the Taras Shevchenko NUK], 51, 124-131. $<$ http://nbuv.gov.ua/UJRN/Znpviknu_2016_51_18> (2020, February, 14). [in Ukrainian].

16. Moroz, T. (2017). Byudzhet Minoborony - 2017 : na texnichne pidsylennya vijska spryamuyut $18 \%$ koshtiv, a «bojovi» doplaty zrostut do 6 tysyach [The Ministry of Defense budget - 2017: 18\% of the funds will be used for reinforcement of the troops, and the "combat" surcharges will increase to 6 thousand]. Veterany [Veterans]. $<$ http://veterano.com.ua/index.php?option=com_content\&view=article\&id=3887:byudzhet-minoboroni-2017na-tekhnichne-pidsilennya-vijska-spryamuyut-18-koshtiv-a-bojovi-doplati-zrostut-do-6-tisyach\&catid= 16\&Itemid=214> (2020, February, 14). [in Ukrainian].

17. Odermatt, J. (2013). Between law and reality: "new wars" and "internationalized armed conflict". Amsterdam law forum, 5 (3), 19-32. [in English].

18. Shahid, A., Saba, I. (2015). Ekonomichne zrostannya krayin i vijskovi vytraty: analiz vzayemozvyazku [Economic growth and military spending: an analysis of the relationship]. Mizhnarodna ekonomichna polityka [International economic policy], 2 (23), 50-76. [in Ukrainian].

19. SIPRI databases. Stockholm International Peace Research Institute. Official page. $<$ https://www.sipri.org/databases $>$ (2020, February, 14). [in English].

20. Skrynchenko, B. (2015). Razvitie voennoj ekonomiki v 20-m veke [The development of the war economy in the 20th century]. Vestnik Moskovskogo universiteta imeni S. Ju. Vitte. Serija: Ekonomika i upravlenie [Bulletin of Moscow S. Yu. Witte University. Series: Economics and Management], 1 (12), 57-61. [in Russian].

21. Ministry of Finance of Ukraine (2020). Statystychnyj zbirnyk [Statistical collection]. $<$ https://www.mof.gov.ua/uk/statistichnij-zbirnik> (2020, February, 14). [in Ukrainian].

22. Food and agriculture organization of the United Nations (2017). The state of Food security and Nutrition in the world 2017: Building Resilience for Peace and Food security. <http://www.fao.org/3/a-i7695e.pdf > (2020, February, 14). [in English].

23. United Nations, World Bank. (2018). Pathways for Peace: Inclusive Approaches to Preventing Violent Conflict. Washington, DC: World Bank. <https://openknowledge.worldbank.org/handle/10986/28337> (2020, February, 14). [in English].

24. Vacyak, Ya. (2019). Vijskovi vytraty Ukrayiny zrosly na 21\% [Ukraine's military expenditures increased by $21 \%$ ]. Ukrayinski novyny [Ukrainian news]. <https://ukranews.com/ua/news/629282-vijskovi-vytraty-svitu-i-ukrayinyzrosly> (2020, February, 14). [in Ukrainian].

25. Ministry of Finance of Ukaine (2020) Valovyj vnutrishnij produkt v Ukrayini [Gross domestic product in Ukraine]. $<$ http://index.minfin.com.ua $>$ economy $>$ gdp $>$ (2020, February, 14). [in Ukrainian].

26. Public audit (2019).Yak ekonomika Ukrayiny opynylasya na dni ta yak vyvesty yiyi z teperishnogo stanu 2019 [How Ukraine's economy sank to the bottom and how to bring it back to its present state in 2019]. $<$ http://publicaudit.com.ua/reports-on-audit/globalnyj-analiz-bazovyh-makroekonomichnyh-pokaznykiv-ukrayiny2013-2018-rr/> (2020, February, 14). [in Ukrainian]. 